\title{
GENDANG LIMAPULUH KURANG DUA PADA MASYARAKAT ETNIS KARO DI SUMATERA UTARA \\ Oleh: \\ Wiflihani*
}

\begin{abstract}
Abstrak
Lewat media iringan bunyi-bunyian (musik), cerita mitos kejadian dunia (kosmogoni) pada satu masyarakat tertentu disajikan dengan sedemikian indah dan terasa menggugah perasaan bagi siapa saja yang mendengarkannya meskipun tidak melalui dialog secara literer. Demikian pula dengan Gendang Karo Limapuluh Kurang Dua yang berisi tentang cerita kosmogoni yang dipercayai oleh masyarakat Karo. Melalui media musik yang disajikan oleh 4 orang Sierjabaten yang terdiri dari: pengual 1, pengual 2, penarune dan penabuh gong. Gendang ini berdurasi hampir 2 jam yang terbagi dalam 6 frase, terdiri dari 48 gendang tanpa teks tertulis, dan mempunyai makna dan arti berlainan antara satu gendang dengan gendang yang lain. Teriakan allep-allep sebanyak 3 kali yang artinya luapan tanda gembira (hore-hore) oleh semua yang hadir, selalu menjadi tanda bagi setiap akhir dan memulai frase.
\end{abstract}

\section{Kata Kunci: Gendang Limapuluh Kurang Dua, Etnis Karo, Sumatera Utara}

\section{A. Masyarakat Karo}

Pembagian daerah administrative Tk.II di Indonesia khususnya Sumatera Utara terjadi setelah kemerdekaan RI 1945 (Singarimbun, 1975: 1). Sebagaimana yang diketahui bahwa persebaran masyarakat Karo di daerah Propinsi Sumatera Utara di kategorikan luas karena menempati beberapa daerah kabupaten di Sumatera Utara. Etnis Karo bukan hanya berdiam di daerah Kabupaten Karo saja, mereka berdiam di daerah-daerah tetangganya seperti di kabupaten Deli Serdang, Langkat, Simalungun, Dairi, Aceh Tenggara, Kodya Medan, Kodya Binjai, dan berbagai tempat di belahan nusantara kita ini. Menurut perhitungan kasar tahun 1985 tidak kurang dari 500.000 jiwa jumlah masyarakat Karo yang ada di daerah-daerah luar Kabupaten Karo ( Bangun, 1986: 13 ).

Persebaran masyarakat Karo yang mendiami daerahdaerah di luar Kabupaten Karo ini sebenarnya telah terjadi jauh sebelum Belanda menjajah wilayah yang didiami suku Karo sekitar tahun 1906, khususnya yang tinggal di dataran tinggi Karo sekarang (Pemda Dati.II Karo, 1981:3).Setelah Belanda menginjakkan kakinya di daerah wilayah Karo, maka daerah ini

\footnotetext{
* Dosen Program Studi Pendidikan Seni Musik, FIS - UNIMED
} 
dibagi-bagi oleh Belanda menjadi wilayah pemerintahan yaitu Onderafdeling Karo-Landen di pimpin controleur dimana pimpinan pemerintahan berada di tangan Belanda. Di samping itu ada pula pemerintahan Bumiputera (lands-chaap) yang dibentuk berdasar "perjanjian pendek"(Korte Verklaring) tahun 1907 dan dibagi menjadi 5 landschaap yang dikepalai oleh Sibayak. Di bawah landschaap ada lagi kerajaan lebih kecil yang bernama Raja Urung. Daerah Onderafdeling digabung pula dengan Simalungun, yang kemudian dijadikan sebuah Afdeling dengan ibukotanya Pematang Siantar yang dikepalai seorang Asisten Residen berkebangsaan Belanda (Singarimbun, 1975:9)

Setelah Indonesia merdeka, daerah yang didiami oleh sebagian suku Karo dijadikan satu kabupaten, mencakup Kabupaten Karo sekarang ditambah wilayah Karo Jahe/Dusun dengan tiga wilayah kewedanan yaitu Kabanjahe, Tigabinanga, dan Deli Hulu. Pada tahun 1958, Kewedanan Deli Hulu yang terbagi dalam 15 kecamatan kemudian dimasukkan ke dalam wilayah Kabupaten Deli Serdang (Bangun, 1986:15).

Persebaran yang luas sulit untuk memberi batasan demografi, mengingat sistem polietnik yang menempati daerah Sumatera Utara. Menurut pandangan Barth tentang kasus masyarakat yang menempati daerah polietnis, bahwa batas etnik tetap ada walaupun terjadi "penyusupan" populasi. Selanjutnya menurut Barth, perubahan identitas etnik dapat berubah dengan adanya interaksi polietnik (Barth, 1988:23). Seperti halnya di Sumatera Utara, khususnya masyarakat Karo misalnya dengan sekitarnya tetapi tetap ada menunjukkan keakuan yang sama pada pola budaya etnik tersebut, yang tetap menjadi cirinya. Demikian juga halnya dengan masyarakat Karo yang mendiami geografi polietnik dan mendapat kebijaksanaan dari berbagai pihak, baik kolonialisme dan pemerintah RI, tetapi tetap memiliki yang menjadi cirinya. Mengenai masalah batasan etnik ini tidak akan penulis bahas lebih lanjut.

\section{B. Kepercayaan, Kosmogoni dan Gendang Limapuluh Kurang Dua}

Kosmogoni lebih bersifat mitos, yaitu tentang penciptaan alam semesta yang ada pada bangsa-bangsa di atas muka bumi dan secara umum terbagi menjadi dua. Pertama, menceritakan bahwa alam semesta berawal dari ketidakteraturan atau sesuatu yang tanpa bentuk, yaitu air. Hal itu dapat dipahami karena umumnya peradaban terbentuk di sekitar tepi sungai di mana air memegang peranan penting bagi kehidupan. Air sebagai awal penciptaan umumnya dikisahkan oleh masyarakat agraris. Itu pun bisa 
dipahami karena air sangat penting buat pengairan sawah dan ladang mereka. Kedua, menceritakan bahwa alam semesta diciptakan dari ketiadaan dengan dewa-dewa atau Tuhan sebagai penciptanya. (www.wikipedia.co.id)

Kepercayaan lama orang Karo disebut dengan perbegu yang terdiri dari kata dasar begu yang berarti roh orang yang sudah meninggal. Namun kata begu tersebut sering juga diartikan sebagai hantu (kerajaan maut). Dalam Kamus Karo Indonesia (Ginting, 1995) begu diartikan sebagai bayangan orang mati, rohnya atau setannya, keadaan sesudah mati, akhirat, gelap. Kata awalan 'per' dalam kata begu tersebut menyatakan orang [seseorang] yang terkait dengan kata begu itu sendiri. Jadi perbegu dapat diartikan sebagai orang yang masih terkait dengan begu, atau yang mempercayai, menyembah begu. Inilah yang dianggap sebagai kepercayaan lama orang Karo dengan menyebut kebenaran, yaitu penguasa langit dan bumi dengan sebutan Dibata (Prinst: 1985).

Kepercayaan perbegu pada masyarakat Karo sebenarnya tidak monoteisme, meskipun dikenal istilah Dibata. Jika dilihat dalam fungsi dan perannya, maka sebenarnya orang Karo menganut kepercayaan yang bersifat politeisme, yaitu Thei yang lebih dari satu. Sebenarnya sebelum kedatangan agama Kristen dan Islam masuk dalam kehidupan masyarakat Karo, peradaban masyarakat Karo telah mencapai tingkatan transendental yaitu percaya kepada Tuhan Yang Maha Esa, yang menciptakan segala yang ada di bumi dan di alam jagat raya ini. Bukti adanya kepercayaan terhadap Tuhan Yang Maha Esa ini adalah dilakukannya pemujaan di tempat-tempat tertentu seperti di bawah pohon kayu yang besar, pada batu-batu yang besar (Bangun: 1985).

Gendang Limapuluh Kurang Dua berkaitan dengan kejadian terciptanya dunia menurut masyarakat Karo (filosofi kosmogoni) yang termasuk dalam kosmogoni kedua yaitu menceritakan bahwa alam semesta diciptakan dari ketiadaan dengan dewa-dewa atau Tuhan sebagai penciptanya. Dalam Mitos kepercayaan orang Karo, cerita tentang kejadian dunia diawali dengan adanya peperangan (kekacauan), yang terjadi sebanyak 4 kali. Menurut Prinst, kejadian tersebut bisa diartikan adanya penggambarkan pergolakan-pergolakan yang terjadi pada kehidupan di dunia.

Dalam paparan Prinst, disebutkan bahwa pertama sekali Dibata (Tuhan) menciptakan dunia (dunia masih muda), kemudian selanjutnya menciptakan 3 anak yang ditempatkan di atas, tengah dan bawah. Dalam mitos kepercayaan orang Karo, hal ini ditandai 
dengan adanya tiga perwujudan Dibata (Tuhan), yaitu Dibata Kaci-Kaci (Dibata Datas $=$ Tuhan yang berkuasa di langit). Tuhan yang menguasai alam yang di atas; Dibata Padukah Ni Aji (Dibata Tengah = Tuhan yang berkuasa di bumi). Tuhan yang menguasai alam bagian tengah yaitu Bumi; Dibata Banua Koling (Dibata Teruh = Tuhan yang berkuasa di bawah bumi). Tuhan yang menguasai bawah tanah.

Akan tetapi dalam cerita ini, ketiganya selalu berkelahi pada awalnya, sehingga membuat Dibata (Tuhan) kebingungan. Oleh karena itu, diciptakanlah pemisah/sekat bagi mereka dan ditempatkan satu di Langit/Surga (atas), satu di Dunia/Bumi (tengah) dan satu lagi di Dunia Kematian (bawah). Namun, anak yang berada di bawah selalu marah karena tidak dapat melihat saudaranya yang lain, sehingga diciptakanlah angin puting beliung dari 8 arah penjuru mata angin untuk menghembus sekat pemisah tersebut sampai berantakan.

Kejadian ini berulang sampai 4 kali dan terjadilah asal muasal Desa Si Waluh (delapan) dan Si Empat (empat) bagi masyarakat Karo yang artinya ke empat arah penjuru mata angin yaitu timur, selatan, barat dan utara. Desa si waluh yaitu tempattempat berdasarkan pembagian ke dalam delapan pengelompokan dasar, yaitu 8 arah mata angin, yaitu purba (timur), aguni (tenggara), daksina (selatan), nariti (barat daya), pustima (barat), mangabia (barat laut), butara (utara), dan irisen (timur laut).

Delapan penjuru angin ini dapat lagi dibedakan atas dua pengolongan besar, yaitu dua sifat yang berbeda. Penggolongan ini adalah desa nggeluh dan desa mate. Desa nggeluh berarti arah hidup, yaitu untuk arah mata angin timur, selatan, barat dan utara, sedangkan desa mate adalah selain arah mata angin yang dikategorikan desa nggeluh. Pengolongan kepada arah hidup dan arah mati ini didasarkan karena desa-desa timur, selatan, barat dan utara dikuasai oleh roh-roh penolong yang memberikan kebahagiaan kepada manusia. Sementara desa mate diyakini sebagai tempat makhluk-makhluk gaib yang dapat mencelakan manusia.

Cerita kemudian berlanjut dengan Dibata (Tuhan) menidurkan ketiga anaknya selama tujuh hari tujuh malam dan kembali membuatn sekat-sekat lagi. Akan tetapi pada hari ke delapan, ketiga anak tersebut terbangun, maka anak yang berada di bawah kembali marah dan menciptakan angin puting beliung untuk menghembus atau menghancurkan penyekat/pemisah tersebut. Dunia pada saat itu diceritakan masih labil, maka dengan kejadian tersebut, terjadilah gunung-gunung, lembah, ngarai, lautan dan lain-lain. 
Untuk membuat keadaan dunia tenang karena selalu terjadi kegemparan oleh ketiga anaknya yang terpisah, maka Dibata (Tuhan) menurunkan guru (dukun) untuk masyarakat Karo agar menjadi penghubungkan diantara ketiga anak yang berada di Atas, Tengah, Bawah. Demikianlah mitos kepercayaan tentang kosmogoni pada masyarakat Karo yang sampai sekarang masih dipercaya pada beberapa kelompok yang masih menganut ajaran pemena.

Guru adalah sebuah peranan yang mencakup luas dan mempunyai kaitan erat sekali dengan konsepsi tentang kosmos sebagai pelaksana utama dalam ritus tertentu pada masyarakat Karo. Mengingat bahwa titik sentral dan tujuan utama segala aktivitas peranan guru adalah untuk mencapai kembali keseimbangan, baik itu keseimbangan di antara manusia itu sendiri, maupun keseimbangan dengan lingkungannya, yaitu makro kosmos dalam arti yang lebih luas. Oleh sebab itu khusus dalam upacara-upacara ritual peran guru sangat dominant, karena guru dianggap memiliki pengetahuan yang cukup luas dan mendetail tentang berbagai hubungan dengan kehidupan dan kejadian alam.

\section{Gendang Dalam Masyarakat Karo}

Gendang dalam bahasa Karo pada dasamya mengandung 2 (dua) pengertian mendasar. Pertama, menyatakan salah satu alat musik yang terdapat dalam musik tradisional Karo, yaitu alat musik pukul (membranophone, double headed conical drum) yang sebutan lengkapnya adalah gendang singanaki dan gendang singindungi. Kedua, menyatakan upacara yang disertai dengan musik tradisional Karo. Artinya, dengan menyebutkan "gendang", maka secara temurun akan diartikan sebagai alat musik tersebut atau suatu aktivitas adat yang di dalamnya terdapat musik tradisional Karo. Apabila kata gendang diberi imbuhan (awalan dan akhiran) maka pengertiannya menjadi berubah, dan lebih penting lagi, apabila kata gendang dirangkai dengan kata yang lain maka pengertiannya sangat tergantung pada kata yang mengikutinya.

Ergendang (ditambah awalan er yang berarti melakukan sesuatu) pengertiannya adalah bermain musik (dalam pengertian musik tradisional Karo). Igendangi (awalan dan akhiran "i" keduanya mengandung pengertian disertai dengan) menyatakan suatu upacara disertai dengan musik tradisional Karo. Jika kata gendang dirangkai dengan satu atau dua kata yang lain, maka pengertiannya menjadi berubah-ubah, tergantung dengan kata yang dirangkaikan terhadap kata gendang tersebut. 
Demikian kaya dan unik dengan beragam istilah yang ada pada masyarakat Karo, sehingga kata gendang bisa mempunyai arti bermacam-macam. Berikut yang dapat diuraikan, ketika kata gendang terdengar dan mereka sebutkan, merupakan:

1. Judul satu komposisi, misalnya gendang simalungen rayat, gendang simalungen timur, gendang patam patam.

2. Ensambel, misalnya gendang lima sedalanen, gendang telu sedalanen.

3. Upacara yang disertai dengan musik tradisional, misainya gendang cawir metua, gendang guro-guro aron.

4. Repertoar (satu repertoar terdiri dari beberapa judul komposisi lagu), misalnya, gendang lima puluh kurang dua. Gendang lima puluh kurang dua terdiri dari 48 (empat puluh delapan) judul gendang (komposisi).

5. Nama alat musik (instrumen) tradisional Karo secara khusus yaitu gendang singanak dan gendang singindungi.

6. Repertoar dan sekaligus menjelaskan jenis upacara tertentu, yaitu gendang erpangir ku lau. Erpangir ku lau adalah satu ritual kepercayaan pada masyarakat Karo yang memiliki beberapa tujuan tertentu. Jika disebutkan gendang erpangir $k u$ lau maka terdapat beberapa judul komposisi (repertoar) yang harus dimainkan, yaitu: perang alep empat kah, gendang peselukken, gendang pengindon guru, gendang adot, gendang pendungi, dan gendang adat. Dengan mengatakan gendang erpangir $k u$ lau telah menjelaskan dua hal yaitu repertoar tertentu serta jenis upacara tertentu pula.

7. Satu bagian (sesi) dari sebuah upacara adat yang disertai gendang lima sedalanen, misalnya gendang serayaan, gendang manganak karo. Gendang serayaan merupakan suatu bagian dari upacara perkawinan yang disertai dengan musik tradisional Karo.

\section{Gendang Karo Limapuluh Kurang Dua Dan Keberlanjutannya \\ Demikianlah Gendang Karo Limapuluh Kurang Dua yang} berisi tentang cerita kosmogoni yang dipercayai oleh masyarakat Karo. Sebutan Limapuluh kurang dua adalah istilah sehari-hari pada masyarakat Karo dalam hal jual beli, seperti menggenapkan sesuatu kalau kurang berarti minus dan kalau tambah adalah plus. Dan sayangnya masih belum terjawab yang 48 lagu dan tidak diceritakan, akan tetapi selalu yang diceritakan adalah yang kurang dua yaitu untuk Sang Pencipta dan roh-roh leluhur .

Memang tidak bisa dipungkiri, bahwa eksistensi Gendang Karo Limapuluh Kurang Dua ini sangat sulit untuk ditemukan lagi 
pada masyarakat karo. Penulis kebetulan sekali menyaksikan secara langsung pada tanggal 15 Nopember 2002 pukul 20.00 WIB bertepatan dengan bulan Ramadhan di Jalan Hang Jebat no. 3 Medan Sumatera Utara, markas Habitat Seni Lak-lak. Selain diadakan pertunjukan, juga diadakan diskusi dan Tanya jawab dengan beberapa tokoh seperti Darwin Prinst, seorang tokoh adat karo yang sekarang sudah meninggal, Subanindyo Hadiluwih, seorang tokoh seni dan budaya, beberapa sierjabaten yang memang khusus diundang untuk mempersembahkan Gendang Karo Limapuluh Kurang Dua dan juga beberapa generasi muda seniman Medan.

Gendang ini memang sangat sulit untuk ditemui sekarang, selain menemukan sierjabaten yang mampu memainkan gendang ini, juga bagaimana sulitnya mencari guru yang masih bisa menerjemahkan musiknya. Salah satu penyebabnya adalah dengan tersingkirkannya kepercayaan awal masyarakat Karo yaitu pemena dengan datangnya agama-agama yang kemudian datang. Kejadian tersebut juga menjadikan tersingkir pulalah kesenian tradisi karena guru sebagai garda depan tidak lagi mendapat tempat dalam masyarakatnya. Selain itu juga tak seorangpun berani mewarisi seluruh kemampuan yang merupakan hak istimewa dari guru dan sierjabaten tersebut.

Akibatnya adalah orang Karo sendiri tidak lagi percaya dengan budayanya sendiri, dan menyebut orang yang menguasai tradisi Karo semacam guru/ahli pengobatan/dukun sebagai si pele begu (penyembah hantu), kaum kafir, parbegu. Pada akhirnya orang Karo sendiri menjadi takut untuk mendalaminya karena adanya sebutan tersebut.

Masalah regenerasi menjadi persoalan juga bagi sierjabaten, karena hampir Sembilan tahun sudah berlalu, pada saat gendang ini dimainkan, Bapak Tarigan seorang yang masih hidup dan hafal dengan Gendang Limapuluh Kurang Dua. Penulis tidak mengetahui lagi sekarang, apakah beliau masih hidup ataukah sudah meninggal. Apabila sudah meninggal, maka sudah barang tentu tidak ada lagi yang menguasainya yang berarti punah sampai di sini, karena sudah tidak ada penerusnya.

Untuk menguasainya, apabila dilakukan secara alami akan memakan waktu yang lama, karena menurut penuturan beliau pada waktu itu, setelah 30 tahun praktek meniup sarune, baru bisa menguasai dan menjadi penarune yang harus memainkan terus dari awal sampai akhir tanpa teks ke 48 lagu secara berurutan.

Selain adanya gempuran kepercayaan baru yang datang, penyebab yang lain adalah danya alat musik elektronik yang lebih terkenal dengan sebutan keyboard, sudah banyak menggantikan 
alat musik tradisi. Hal ini bisa dilihat pada setiap upacara apakah itu perkawinan ataupun kematian semuanya sudah memakai keyboard, yang pada akhirnya mengaburkan ciri antara upacara tersebut. Dan yang terjadi adalah begitu sulitnya membedakan antara upacara kematian dan upacara perkawinan, karena kedua upacara tersebut memakai alat musik yang sama yaitu keyboard.

Secara psikologis juga, banyak orang-orang Karo merasa lebih rendah derajatnya dari orang lain ketika mereka memahami, mendalami dan menggunakan hal-hal yang berkaitan dengan tradisi Karo. Dan ketika memakai lagu-lagu dan musik tradisi Karo ada anggapan lebih rendah juga dari orang Karo lain yang menggunakan keyboard.

Ada satu hal yang patut dipertanyakan, ketika mengacu pada makna fungsi, kalau memang suatu masyarakat sudah tidak memfungsikannya lagi, untuk apa hal tersebut digali dan dimunculkan lagi. Bisakah fungsinya dirubah dengan tidak mengurangi kandungan isinya?...

\section{Daftar Pustaka}

Bachtiar, Harsya W. 1991. Pengamatan Sebagai Suatu Metode Penelitian dalam Metode-Metode Penelitian Masyarakat (Koentjaraningrat, red). Jakarta: Gramedia Pustaka Utama

Bandem, I Made dan Sal Murgianto. 1996. Teater Daerah Indonesia. Denpasar: STSI Denpasar.

Bangun, Payung. 1985. Kebudayaan Batak dalam Manusia dan Kebudayaan Indonesia (Koentiaraningrat, red) Jakarta: PT Jambatan

Bangun, Roberto. 1989. Mengenal Orang Karo, Jakarta: Yayasan Merga Silima

Bangun, Tridah. 1986. Manusia Batak Karo, Jakarta: Inti Idayu Press

Barth, F. 1988. Kelompok Etnik dan Batasannya. Jakarta : UI Press.

Behaque, G. 1984. Performance Practice : Ethnomusicological Perspectives. USA: Greenwood Press.

Bukit, M. 1994. Sejarah Kerajaan dan Adat Istiadat Karo, Hasil Kongres 1965, Kabanjahe: Toko Bukit.

Ginting, 1995. Kamus Karo Indonesia, Medan: Bina Media.

Ginting, Juara R.1986. Pandangan Tentang Gangguan Jiwa dan Penanggulangannya Secara Tradisional pada Masyarakat Karo, Medan: Skripsi Sarjana FISIP USU.

Gintings, E.P. 1999. Religi Karo. Membaca Religi Karo Dengan Mata Yang Baru. Kabanjahe : Abdi Karya. 
Limbeng, Julianus. 2001. "Sengget dan Fungsinya pada Masyarakat Karo" dalam Harian Pelita, Jakarta.

Lindsay, Jennifer. 1991. Klasik Kitsch Kontemporer: Sebuah Studi Tentang Seni Pertunjukan Jawa, Yogyakarta: Gadjah Mada University Press

Mack, Dieter. 1999. Konsep Peranakan dan Silang Budaya, dalam Jurnal: Keragaman dan Silang Budaya, Jakarta: MSPI.

Mawardi, R dan Iman K.S.,1999. Laporan Kegiatan Inventarisasi Potensi Wisata Gunungapi Sibayak Tanah Karo, Sumatera Utara.

Merriam, Alan P. 1964. The Anhropology of Music. Chicago: North Western University Prees.

Moderamen GBKP. 2006. Bimbingen Perpulungen Jabu-Jabu, Kabanjahe: Moderamen GBKP.

Pemda Dati II Karo. 1981. Monografi Kabupaten Karo.

Prinst, Darwan \& Darwin Prinst. 1985. Sejarah dan Kebudayaan Karo. Jakarta: cv. GRAMA.

Prints, Darwan. 1996. Adat Karo. Medan : Tanpa Penerbit.

Sebayang, K. 1997. Keyboard (Kibod) Mara Perlandek, gendang Begu dan hadiah Ketupat Bangkahulu alias Bogem Mentah, Tenah No. 80 dan 81, Th VII, Edisi Agustus dan September, hal. 22-28 dan hat 6-10)

Sedyawati, Edy. 1981. Pertumbuhan Seni Pertunjukan. Jakarta: Sinar Harapan. Sitepu, Sempa. 1982. Pilar Budaya Karo Medan: "Bali" Scan.

Sembiring, Sri Alem. 2002. Guru (Tabib) dalam Masyarakat Karo: Kajian Antropologi mengenai Konsep Orang Karo tentang Guru dan Kosmos (Alam Semesta), Medan: FISIP USU.

Sembring , B. 1995. Transformasi Alat Musik Pengiring, Tenah No. 54, Th V, Edisi Juni, hal. 14-16

Sinuraya, R, 1983. Laporan Monitoring G.Sibayak, Kab. Karo, Kantor Wilayah Pertambangan dan Energi, Prop. Sumatera Utara.

Siregar, S. Dkk. 1985. Kamus Karo - Indonesia. Jakarta : Pusat Pembinaan dan Pengembangan Bahasa Departemen P \& K.

Sitepu, Sempa, Dkk. 1996. Pilar Budaya Karo. Medan : Perc.Bali

Soedarsono, R.M. 1985. "Peranan Seni Budaya dalam Sejarah Kebudayaan Manusia Kontinuitas dan Perubahannya". Pidato Pengukuhan Jabatan Guru Besar pada Fakultas Sastra, Universitas Gajah Mada, Yogyakarta, 9 Oktober 1985. 
Steedly, Mary Margaret, 1993. Hanging Without a Rope: Narrative Experience in Colonial and postcolonial Karoland, USA: Princeton Studies in Culture.

Takari, Muhammad. 2004. "Masyarakat Karo dan Seni Pertunjukannya", dalam Harian Waspada, 24 Pebruari 2004.Bandem, I Made. 1985. Etnologi Tari. Denpasar: Proyek Pengembangan Institut Kesenian Indonesia Sub/bagian Proyek Peningkatan dan Pengembangan Akademi Seni Taris Indonesia, Denpasar.

Tambun, P, Dkk. 1958. Sejarah Adat Istiadat dan Tata Susunan Rakyat Karo. Kabanjahe:UP. Bukit Mbelin Gunana.

Tarigan, Perikunten: Perubahan Alat Musik Dalam Kesenian Tradisional Karo Sumatera Utara, 2004. USU eRepository CO 2008 